\title{
Cassette Dosing Unit
}

National Cancer Institute

\section{Source}

National Cancer Institute. Cassette Dosing Unit. NCI Thesaurus. Code C69093.

A dosing unit equal to the amount of active ing redient(s) contained in a cassette. 